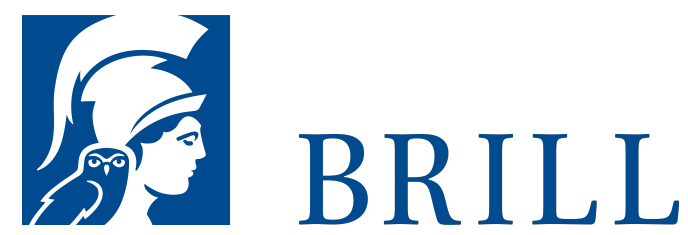

\title{
Geist und Gegenwart
}

Entwurf einer analytischen Transzendentalphilosophie

\section{Author: Peter Rohs}

Die Zeitbestimmungen, die in dem sogenannten »Verfließen der Zeit « begründet sind (wie die vergehende Gegenwart), spielen für unsere geistige Existenz eine fundamentale Rolle. In dem Buch soll gezeigt werden, dass sich wesentliche Eigenarten unserer Erkenntnisfähigkeiten, aber auch die kausale Wirksamkeit des Geistes in der physischen Welt auf dieser Grundlage befriedigend verstehen lassen. Ein starker Freiheitsbegriff, der die Möglichkeit einschließt, etwas Neues zu beginnen, kann auf diese Weise gerechtfertigt werden. Das Ergebnis ist ein nicht-naturalistischer Dualismus, freilich nicht der Substanzen, sondern der zeittheoretischen Basis entsprechend der Prozesstypen. Ein solcher Dualismus, der weder den Gesetzen der Physik noch den Tatsachen der Evolution widerspricht, erlaubt es, an den herkömmlichen Merkmalen von Personalität festzuhalten.

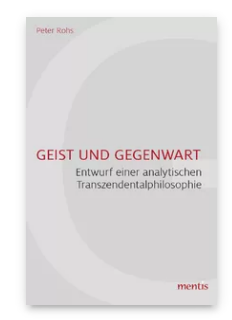

Pages: 203

Seiten

Language:

German

Subjects:

General,

Philosophy

Publisher: Brill | mentis

E-Book (PDF)

Released online:

o1 Dec 2016

ISBN: 978-3-

95743-799-0

List price

Paperback

Publication date:

28 Nov 2016

ISBN: 978-3-

95743-071-7

List price 
For more information see brill.com

Order information: Order online at brill.com +44330 333 0049 | customerservices@brill.com Submission information: brill.com/authors

Titles published by Brill | Fink, Brill | mentis or Brill | Schöningh: +49(o)715413279216| brill@brocom.de 